\title{
LA INCONSTITUCIONALIDAD DEL REAL DECRETO-LEY 13/2005 POR EL QUE SE MODIFICA LA LEY DEL PATRIMONIO SINDICAL ACUMULADO. COMENTARIO DE LA STC 125/2016, DE 7 DE JULIO
}

\author{
Entique CABERO MORÁN \\ Profesor Titular de Derecho del Trabajo \\ y de la Seguridad Social \\ Facultad de Derecho de la Universidad de Salamanca \\ ecaberom@usal.es
}

\section{INTRODUCCIÓN}

La Sentencia del Tribunal Constitucional (STC) 125/2016, de 7 de julio (BOE de 10 de agosto de 2016), declara inconstitucional y nulo el Real Decreto-ley 13/2005, de 28 de octubre, por el que se modifica la Ley 4/1986, de 8 de enero, de Cesión de Bienes del Patrimonio Sindical Acumulado, al considerar que su aprobación por el gobierno no se ha ajustado a lo establecido en el art. 86.1 de la Constitución Española de 1978 (CE), el cual establece que: «En caso de extraordinaria y urgente necesidad, el gobierno podrá dictar disposiciones legislativas provisionales que tomarán la forma de decretos-leyes y que no podrán afectar al ordenamiento de las instituciones básicas del Estado, a los derechos, deberes y libertades de los ciudadanos regulados en el título I, al régimen de las Comunidades Autónomas ni al Derecho electoral general».

El gobierno ha aprobado, tras la entrada en vigor de la CE, quinientos veintiséis decretos-leyes, desde el Real Decreto-ley 1/1979, de 8 de enero, por el que se prorroga el tiempo indispensable la actuación de la Junta Central de Acuartelamiento, hasta el Real Decreto-ley 1/2017, de 20 de enero, sobre medidas urgentes de protección de consumidores en materia de cláusulas suelo. La media, por tanto, se encuentra en catorce decretos-leyes al año. Superan la media los años 1979 (22), 1980 (16), 1981 (19), 1982 (26), 1984 (15), 1993 (22), 1996 (17), 1997 (29), 1998 (20), 1999 (22), 2001 (16), 2005 (16), 2011 (20), 2012 (29), 2013 (17) у 2014 (17). Se sitúan a la cabeza los años 1997 y 2012 con veintinueve decretos-leyes 
cada uno. Téngase presente que el 25,28 por 100 se ha dictado entre los años 2008 a 2015, ambos incluidos, y que el 17,11 por 100 abordan materias vinculadas a las relaciones laborales y de protección social, también desde la dimensión puramente presupuestaria, a fin de dotar los recursos financieros precisos para la atención de las prestaciones económicas ${ }^{1}$. Destacan principalmente por la relevancia de los decretos-leyes aprobados en la modificación de las legislaciones laboral y de Seguridad Social ${ }^{2}$ los años $1993^{3}, 1997^{4}, 1998^{5}, 2001^{6}, 2002^{7}, 2004^{8}, 2006^{9}, 2009^{10}, 2010^{11}$,

${ }^{1}$ Esta última dimensión se concentra especialmente en los años 1981 y 1982. Vid. en esta materia, por ejemplo, el Real Decreto-ley 10/1981, de 19 de junio, sobre inspección y recaudación de la Seguridad Social; el Real Decreto-ley 13/1981, de 20 de agosto, sobre determinación de la base reguladora de la pensión de jubilación en la Seguridad Social; el Real Decreto-ley 1/1982, de 15 de enero, por el que se crea el Fondo Especial de Protección al Desempleo; el Real Decreto-ley 15/1982, de 3 de septiembre, sobre medidas presupuestarias urgentes en materia de defensa y Seguridad Social, y el Real Decretoley 23/1982, de 29 de diciembre, por el que se prorroga la aplicación del Fondo Especial de Protección al Desempleo.

2 En 2005, además, como se sabe, se promulgó el Real Decreto-ley 13/2005, de 28 de octubre, por el que se modifica la Ley 4/1986, de 8 de enero, de Cesión de Bienes del Patrimonio Sindical Acumulado, contra el que fue interpuesto el recurso de inconstitucionalidad que resuelve la sentencia objeto de estudio en este comentario.

${ }^{3}$ Real Decreto-ley 18/1993, de 3 de diciembre, sobre medidas urgentes de fomento de la ocupación.

${ }_{4}$ Real Decreto-ley 8/1997, de 16 de mayo, sobre medidas urgentes para la mejora del mercado de trabajo y el fomento de la contratación indefinida, y Real Decreto-ley 9/1997, de 16 de mayo, por el que se regulan incentivos en materia de Seguridad Social y de carácter fiscal para el fomento de la contratación indefinida y la estabilidad en el empleo.

5 Real Decreto-ley 15/1998, de 27 de noviembre, sobre medidas urgentes para la mejora del mercado de trabajo en relación con el trabajo a tiempo parcial y el fomento de su estabilidad.

${ }^{6}$ Real Decreto-ley 5/2001, de 2 marzo, sobre medidas urgentes de reforma del mercado de trabajo para el incremento del empleo y la mejora de su calidad, y Real Decretoley 16/2001, de 27 de diciembre, sobre medidas para el establecimiento de un sistema de jubilación gradual y flexible.

${ }^{7}$ Real Decreto-ley 5/2002, de 24 de mayo, sobre medidas urgentes para la reforma del sistema de protección por desempleo y mejora de la ocupabilidad.

${ }^{8}$ Real Decreto-ley 3/2004, de 25 de junio, sobre la racionalización de la regulación del salario mínimo interprofesional y para el incremento de su cuantía, y Real Decretoley $11 / 2004$, de 23 de diciembre, por el que se modifica, en materia de pensiones públicas, la Ley de Presupuestos Generales del Estado para el año 2005.

9 Real Decreto-ley 5/2006, de 9 de junio, para la mejora del crecimiento y del empleo.

${ }_{10}$ Real Decreto-ley 2/2009, de 6 de marzo, sobre medidas urgentes para el mantenimiento y el fomento del empleo y la protección de las personas desempleadas, y Real Decreto-ley 13/2009, de 26 de octubre, por el que se crea el Fondo Estatal para el Empleo y la Sostenibilidad Local.

${ }^{11}$ Real Decreto-ley 10/2010, de 16 de junio, sobre medidas urgentes para la reforma del mercado de trabajo. 
$2011^{12}, 2012^{13}, 2013^{14}, 2014^{15}, 2015^{16}$ y $2016^{17}$. La promulgación de la mayoría de estos decretos-leyes se fundamenta, y así se explica en sus exposiciones de motivos, en razones de extraordinaria y urgente necesidad derivadas de la decisión de adoptar nuevas políticas activas de empleo en situaciones graves de desempleo. El repaso del listado de los decretos-leyes aprobados desde 1979 conduce a la conclusión de que el gobierno de España acude a esta vía cada vez con más soltura, sabedor de que la justificación de los requerimientos contemplados al respecto en el art. 86.1 CE, singularmente la relativa a la extraordinaria y urgente necesidad, no está sometida a pautas muy exigentes. Merece la pena, por consiguiente, volver a valorar estos extremos con motivo del comentario de la STC 125/2016, de 7 de julio, pronunciado por el Pleno en resolución del recurso de inconstitucionalidad 1044-2006 y publicada en el Boletín Oficial del Estado el 10 de agosto de 2016.

\section{EL FUNDAMENTO CONSTITUCIONAL DEL DECRETO-LEY Y EL MARCO PARA SU APROBACIÓN}

El citado art. 86.1 CE, ubicado en el capítulo II, «De la elaboración de las leyes», del título III, «De las Cortes Generales», introduce la posibilidad de que el gobierno dicte, en caso de extraordinaria y urgente

12 Real Decreto-ley 7/2011, de 10 de junio, sobre medidas urgentes para la reforma de la negociación colectiva.

13 Real Decreto-ley 3/2012, de 10 de febrero, sobre medidas urgentes para la reforma del mercado laboral; Real Decreto-ley 28/2012, de 30 de noviembre, sobre medidas de consolidación y garantía del Sistema de la Seguridad Social, y Real Decreto-ley 29/2012, de 28 de diciembre, sobre mejora de gestión y protección social en el Sistema Especial para Empleados de Hogar y otras medidas de carácter económico y social.

${ }^{14}$ Real Decreto-ley 4/2013, de 22 de febrero, sobre medidas de apoyo al emprendedor y de estímulo del crecimiento y de la creación de empleo, y Real Decreto-ley 11/2013, de 2 de agosto, para la protección de los trabajadores a tiempo parcial y otras medidas urgentes en el orden económico y social.

${ }_{15}$ Real Decreto-ley 8/2014, de 4 de julio, sobre aprobación de medidas urgentes para el crecimiento, la competitividad y la eficiencia, y Real Decreto-ley 16/2014, de 19 de diciembre, por el que se regula el Programa de Activación para el Empleo.

${ }_{16}$ Real Decreto-ley 4/2015, de 22 de marzo, para la reforma urgente del Sistema de Formación Profesional para el Empleo en el ámbito laboral.

${ }_{17}$ Real Decreto-ley 1/2016, de 15 de abril, por el que se prorroga el Programa de Activación para el Empleo; Real Decreto-ley 3/2016, de 2 de diciembre, por el que se adoptan medidas en el ámbito tributario dirigidas a la consolidación de las finanzas públicas y otras medidas urgentes en materia social, y Real Decreto-ley 6/2016, de 23 de diciembre, sobre medidas urgentes para el impulso del Sistema Nacional de Garantía Juvenil. 
necesidad, disposiciones legislativas provisionales que tomarán la forma de decretos-leyes. No se trata, por ello, de una opción ordinaria de iniciativa legislativa ofrecida por la $\mathrm{CE}$ al gobierno, en la línea de lo señalado por el art. $87 \mathrm{CE}$, sino de una vía de carácter muy excepcional, aunque notablemente diferente por su naturaleza, de los supuestos de suspensión de derechos y libertades definidos en el art. 55 CE (estados de excepción y de sitio ${ }^{18}$. Se dota al gobierno de la posibilidad de aprobar disposiciones legislativas en ese contexto singular a través de un modelo absolutamente distinto del diseñado para la delegación legislativa (art. 82), con límites esenciales en el objeto de la regulación: «No podrán afectar al ordenamiento de las instituciones básicas del Estado, a los derechos, deberes y libertades de los ciudadanos regulados en el título I, al régimen de las Comunidades Autónomas ni al Derecho electoral general». Ha de sumarse a éstos el límite que se genera con la asunción de competencias por las Comunidades Autónomas: el gobierno de España no podrá regular por decreto-ley materias sobre las que la competencia de legislar corresponda a las Comunidades Autónomas ${ }^{19}$, puesto que habrán de hacerlo, en su caso, los Consejos de Gobierno de éstas, también, como «garantía del principio democrático» ${ }^{20}$, sometidos a las exigencias del art. $86 \mathrm{CE}$ y en los términos previstos por los Estatutos de Autonomía ${ }^{21}$.

${ }_{18}$ Y el estado de alarma, de creación legal. Vid. la Ley Orgánica 4/1981, de 1 de junio, de los Estados de Alarma, Excepción y Sitio, y la STC 111/1983, de 2 de diciembre, la cual se anticipa al debate y afirma que: «La extraordinaria y urgente necesidad no ha de entenderse en el sentido extremo de confinar el decreto-ley para ordenar situaciones -intervenir en acontecimientos- de excepcional amenaza para la comunidad o el orden constitucional» (FJ 6..$^{\circ}$.

${ }_{19}$ En este sentido vid., verbigracia y por todas, la STC 177/1990, de 15 de noviembre, que resuelve el conflicto positivo de competencia 62/1985 promovido por el gobierno de la nación en relación con el Decreto 135/1984, de 13 de septiembre, de la Junta de Galicia, sobre medidas de fomento del sector de construcción naval de Galicia, o la STC 195/2016, de 16 de noviembre, que resuelve el recurso de inconstitucionalidad 5951-2014 interpuesto por el consejo de gobierno del Principado de Asturias en relación con los arts. 4 y 7 del Real Decreto-ley 8/2014, de 4 de julio, sobre aprobación de medidas urgentes para el crecimiento, la competitividad y la eficiencia.

${ }^{20}$ En expresión de la STC 93/2015, de 14 de mayo, que resuelve la cuestión de inconstitucionalidad núm. 7434-2013 planteada por la Sala de lo Social del Tribunal Superior de Justicia del País Vasco en relación con el art. 2.1 del Real Decreto-ley 28/2012, de 30 de noviembre, sobre medidas de consolidación y garantía del sistema de la Seguridad Social $\left(\mathrm{FJ} 5 .^{\circ}\right)$.

${ }^{21}$ Vid. la recentísima STC 211/2016, de 15 de diciembre (BOE de 20 de enero de 2017), que recapitula la doctrina sentada sobre el particular y señala lo siguiente: «Este Tribunal ha considerado que, aunque la Constitución no prevea el decreto-ley autonómico, nada impide que el legislador estatutario pueda atribuir al gobierno de las Comunidades Autónomas la potestad de dictar normas provisionales con rango de ley que adopten la forma de decre- 
Resulta indiscutible, así las cosas, que el decreto-ley no podrá afectar al ordenamiento de las instituciones básicas del Estado ni al contenido de las materias cuyo desarrollo legislativo debe aprobarse por ley orgánica, es decir, «las relativas al desarrollo de los derechos fundamentales y de las libertades públicas, las que aprueben los Estatutos de Autonomía y el régimen electoral general, y las demás previstas en la Constitución» (art. 81.1 CE). No obstante, sí ha suscitado dudas el alcance de la expresión «no podrán afectar [...] a los derechos, deberes y libertades de los ciudadanos regulados en el título I», categoría que supera el contenido de la sección $1 .^{\text {a }}$ de su capítulo II, es decir, los derechos fundamentales y las libertades públicas. Realmente es difícil imaginar un decreto-ley que no afecte a alguno de esos derechos, deberes y libertades, entre los que se encuentran, asimismo, los derechos del capítulo I (arts. 11 a 13), el derecho de igualdad (art. 14), los derechos y deberes de los ciudadanos (sección 2. ${ }^{a}$ del capítulo II) y los derechos contemplados en el seno de los principios rectores de la política social y económica (capítulo III). La jurisprudencia constitucional entiende que el límite ha de ser entendido «de modo que no se reduzca a la nada la figura del decreto-ley, de suerte que lo que se prohíbe constitucionalmente es que se regule un régimen general de estos derechos, deberes y libertades o que vaya en contra del contenido o

to-ley siempre que los límites formales y materiales a los que se encuentren sometidos sean, como mínimo, los mismos que la Constitución impone al decreto-ley estatal (SSTC 93/2015, de 14 de mayo, FFJ $3 .^{\circ}$ a $6 .^{\circ} ; 104 / 2015$ de 28 de mayo, FJ 4. ${ }^{\circ}$, y 38/2016, de 3 marzo, FJ 2. ${ }^{\circ}$, entre otras). Esto es, el Estatuto puede sólo añadir "cautelas o exclusiones adicionales" con el fin de "preservar más intensamente la posición del Parlamento autonómico". Ello implica que, para resolver la impugnación planteada frente al Decreto-ley catalán 4/2012, debamos tomar en consideración tanto la doctrina constitucional relativa al art. 86.1 CE, como los límites que haya podido concretar o añadir el legislador estatutario para el decreto-ley autonómico. En lo que resulta relevante para este proceso, el art. 64.1 EAC se refiere también a la "necesidad extraordinaria y urgente" como presupuesto habilitante para que el gobierno pueda dictar "disposiciones legislativas provisionales bajo las forma de decretoley”. En el examen de esta cuestión hemos de partir de la doctrina de la STC 93/2015, de 14 de mayo, recogida en la STC 230/2015, de 5 de noviembre. Allí señalamos que "un Estatuto de Autonomía no puede atribuir al Consejo de Gobierno autonómico poderes de legislación de urgencia que no estén sujetos, en lo que corresponda, a los límites consignados en el art. 86.1 CE como garantía del principio democrático. En todo caso, el Tribunal Constitucional podrá, aplicando directamente el parámetro constitucional ínsito en dicho principio, controlar la constitucionalidad de la legislación de urgencia que pueda adoptar el citado Consejo de Gobierno". Y añade que "a la hora de enjuiciar la concurrencia del presupuesto habilitante del art. 86.1 CE, esto es, la extraordinaria y urgente necesidad del decreto-ley autonómico, este Tribunal deberá ponderar la competencia autonómica ejercida al efecto, pues la naturaleza y alcance de las competencias autonómicas hacen, en principio, menos necesario el recurso a la aprobación de normas legales de urgencia” (STC 93/2015, FJ 5)» (FJ 3. ${ }^{\circ}$ ). 
elementos esenciales de algunos de tales derechos (STC 111/1983, de 2 de diciembre, FJ 8. ${ }^{\circ}$, confirmada por otras posteriores)». Por ello, éstos son los dos criterios básicos que «deben retenerse a efectos de determinar el alcance de la mencionada cláusula restrictiva sobre el decreto-ley: (i) que la legislación de urgencia no regule el régimen general de los derechos, deberes y libertades del título I CE, y que la interpretación constitucionalmente adecuada tenga en cuenta la configuración constitucional de los derechos en cuestión, su ubicación sistemática, en el título I CE; (ii) el mayor o menor grado de intensidad o rigor de las garantías de las que disfrutan, en virtud de lo que establece el art. $53 \mathrm{CE} \gg^{22}$. En este sentido, no se considera acorde con la CE la regulación general por decreto-ley de la tipificación de las infracciones administrativas y de su régimen de sanciones, aspecto especialmente sensible en materia de derechos subjetivos, pero sí se admiten, por su naturaleza de norma con rango de ley, retoques o cambios concretos del mismo ${ }^{23}$. De no haber sido ésta la jurisprudencia sentada por

${ }^{22}$ De la STC 139/2016, de 21 de julio, que en su FJ 6. ${ }^{\circ}$ asevera además que: «La doctrina de este Tribunal en relación con este punto está recogida en el ATC 179/2011, de 13 de diciembre, FJ $7 .^{\circ}$, de la que se desprende lo siguiente:

1. ${ }^{\circ}$ El art. 86.1 CE impide que con el decreto-ley queden afectados los derechos, deberes y libertades de los ciudadanos regulados en el título I CE, pero este Tribunal ha rechazado una interpretación extensiva de dicho límite que supondría el vaciamiento de la figura del decreto-ley haciéndolo "inservible para regular con mayor o menor incidencia cualquier aspecto concerniente a las materias incluidas en el título I de la Constitución”.

2. ${ }^{\circ}$ La cláusula restrictiva debe ser entendida de modo que no se reduzca a la nada la figura del decreto-ley, de suerte que lo que se prohíbe constitucionalmente es que se regule un régimen general de estos derechos, deberes y libertades o que vaya en contra del contenido o elementos esenciales de algunos de tales derechos (STC 111/1983, de 2 de diciembre, FJ $8 .^{\circ}$, confirmada por otras posteriores).

3. ${ }^{\circ}$ El Tribunal no debe fijarse únicamente en el modo en que se manifiesta el principio de reserva de ley en una determinada materia, sino más bien ha de examinar si ha existido "afectación" por el decreto-ley de un derecho, deber o libertad regulado en el título I CE, lo que exigirá tener en cuenta la configuración constitucional del derecho, deber o libertad afectado en cada caso e incluso su ubicación sistemática en el texto constitucional y la naturaleza y alcance de la concreta regulación de que se trate».

23 Esta interpretación sobre normas legales sancionadoras queda fijada en la STC 3/1988, de 21 de enero, que afirma lo siguiente: «Primeramente, no cabe apreciar que la disposición cuestionada constituya una regulación general del régimen de tal derecho —en el improbable supuesto de que esa regulación general fuese posible respecto a un derecho que agota su eficacia, sin necesidad de mayor desarrollo, en el respeto por el órgano impositor de la sanción de los principios de legalidad y tipicidad—, puesto que se limita a establecer supuestos concretos de infracciones administrativas y las correspondientes sanciones. Y en segundo lugar, y en el aspecto aquí considerado, tampoco puede apreciarse que la norma cuestionada comporte en forma alguna una contravención o menoscabo del contenido o elementos esenciales del Derecho, puesto que la garantía querida por el art. 25.1 C.E., y consistente en que exista una cobertura de la actividad sancionadora de la Administración mediante norma de 
el Tribunal Constitucional (TC), ya desde las SSTC 111/1983 y 3/1988, todas las reformas de la legislación laboral y de seguridad social, entre otras, aprobadas por decreto-ley habrían sido nulas e inconstitucionales ab origine.

Para completar el análisis del meollo del marco constitucional del decreto-ley deviene imprescindible volver a la acotación de la naturaleza de la disposición legislativa que se dicta y a la delimitación de las circunstancias habilitantes. Se está ante una decisión del gobierno, de ahí que se acuda a la denominación de decreto, mas evidentemente no nace de la potestad reglamentaria que la CE le otorga razonablemente en su art. 97, pues de ella emana una disposición legislativa o, en fin, una norma con rango de ley, razón que explica que se acuñe la expresión decreto-ley, y, en concreto, de ley ordinaria, por las razones expuestas en el párrafo anterior. Como se ha advertido, el art. $86 \mathrm{CE}$, empero, no piensa en esta vía como cauce normal de la iniciativa legislativa, lo anuncia claramente dando un nombre diferente al producto de la legislación delegada (decreto legislativo), que responde a otra finalidad muy distinta, sino para que el gobierno esté en condiciones de afrontar, en caso de extraordinaria y urgente necesidad ante la imposibilidad real de tramitar un proyecto de ley que acabe entrando en vigor a tiempo, la aprobación de una disposición legislativa provisional. Repárese en que el adjetivo provisional viene a complementar los rasgos que han de concurrir en el presupuesto fáctico habilitante. Se da una solución provisional motivada por un caso extraordinario y urgente que puede, si se estima preciso, modificar o derogar ${ }^{24}$ el contenido de disposiciones con rango de ley ordinaria (incluso de aquellos preceptos ordinarios que forman parte de una ley orgánica ${ }^{25}$,

rango legal, no se ve contradicha o disminuida al ostentar rango legislativo la norma que se cuestiona» (FJ 8. ${ }^{\circ}$ ). Recientemente, al amparo de esta doctrina constitucional, el art. 21 (con catorce apartados) del Real Decreto-ley 4/2015, de 22 de marzo, para la reforma urgente del Sistema de Formación Profesional para el Empleo en el ámbito laboral, modificó el texto refundido de la Ley sobre Infracciones y Sanciones en el Orden Social aprobado por el Real Decreto Legislativo 5/2000, de 4 de agosto.

${ }^{24}$ Vid. la STC 237/2012, de 13 de diciembre, que resuelve el recurso de inconstitucionalidad 4786-2004 interpuesto por el gobierno de la Generalitat Valenciana contra el Real Decreto-ley 2/2004, de 18 de junio, por el que se modifica la Ley 10/2001, de 5 de julio, del Plan Hidrológico Nacional (y deroga varias de sus disposiciones).

${ }^{25}$ Recuérdense, por ejemplo, y sin ir más lejos, las últimas reformas introducidas en la Ley Orgánica 6/2001, de 21 de diciembre, de Universidades, por el Real Decretoley 14/2012, de 20 de abril, sobre medidas urgentes de racionalización del gasto público en el ámbito educativo; así como el Real Decreto-ley 10/2015, de 11 de septiembre, por el que se conceden créditos extraordinarios y suplementos de crédito en el presupuesto del Estado y se adoptan otras medidas en materia de empleo público y de estímulo a la economía. 
suspender la aplicación de otras o aplazar su entrada en vigor ${ }^{26}$. Es posible, asimismo, si se cumplen las demás exigencias, tanto la transposición por decreto-ley al ordenamiento interno de directivas de la Unión Europea ${ }^{27}$ como la sustitución de normas reglamentarias por preceptos contenidos en el decreto-ley ${ }^{28}$. No cabe, sin embargo, la deslegalización por decretoley, es decir, la modificación de una ley ordinaria para suprimir la materia allí contenida y encomendar su regulación a una norma reglamentaria aprobada por el gobierno ${ }^{29}$.

Desde el principio se ha preferido una interpretación flexible de la provisionalidad que ha desembocado durante los últimos cinco años principalmente, con cierto paroxismo gubernamental, en la aprobación de extensos decretos-leyes transversales y con afán de exhaustividad, así como de otros que se marcan como objetivo la regulación de nuevos o renovados sistemas y figuras jurídicas, sustituyendo plenamente la función constitucional atribuida a las leyes ordinarias ${ }^{30}$. No se ha elegido un modelo

${ }^{26}$ Como dispuso, verbigracia, el Real Decreto-ley 20/2011, de 30 de diciembre, sobre medidas urgentes en materia presupuestaria, tributaria y financiera para la corrección del déficit público, con la Ley 9/2009, de 6 de octubre, sobre ampliación de la duración del permiso de paternidad en los casos de nacimiento, adopción o acogida.

27 Vid. las SSTC 329/2005, de 15 de diciembre, y 1/2012, de 13 de enero, si bien, como indica esta última (FJ 9. ${ }^{\circ}$ ): «El recurso al decreto-ley como cauce de incorporación al ordenamiento interno del Derecho de la Unión Europea por la mera razón de que hubiera transcurrido el plazo de transposición, sin mayores precisiones, no se adecuaría al presupuesto habilitante de la urgente y extraordinaria necesidad, por lo que constituiría un uso abusivo de una facultad excepcional conforme a la Constitución Española como es la legislación de urgencia y conduce a un reforzamiento de la posición institucional del poder ejecutivo en detrimento de la del legislativo [...] De mantenerse otra interpretación se alentaría la progresiva atracción de la incorporación de las directivas hacia el ámbito funcional del decreto-ley, en detrimento de los principios de legitimidad democrática directa y de legalidad que recaen inicialmente en la acción de las Cortes Generales en cuanto que representantes del pueblo soberano».

${ }_{28}$ Así lo hizo, por ejemplo, el art. 4 del Real Decreto-ley 3/2004, de 25 de junio, sobre racionalización de la regulación del salario mínimo interprofesional y para el incremento de su cuantía, en relación con el Real Decreto 1793/2003, de 26 de diciembre, por el que se fija el salario mínimo interprofesional para 2004 con una técnica inversa, por el marco temporal de su aprobación, a la utilizada en la disposición adicional única del Real Decretoley $3 / 2016$, de 2 de diciembre, por el que se adoptan medidas en el ámbito tributario dirigidas a la consolidación de las finanzas públicas y otras medidas urgentes en materia social, dedicada a la fijación del salario mínimo interprofesional para 2017.

${ }^{29}$ Vid. la STC 29/1982, de 31 de mayo, que estima parcialmente el recurso de inconstitucionalidad interpuesto contra el Real Decreto-Ley 10/1981, de 19 de junio, sobre inspección y recaudación de la Seguridad Social, y declara la inconstitucionalidad de su disposición adicional.

${ }^{30}$ Responde a este último modelo, por ejemplo, el Real Decreto-ley 4/2015, de 22 de marzo, para la reforma urgente del Sistema de Formación Profesional para el Empleo en el 
que restrinja el uso del decreto-ley para adoptar una serie de medidas ante el advenimiento de calamidades sísmicas o ambientales ${ }^{31}$. Por el contrario, se ha consolidado como un instrumento para modificar la legislación sin límites temporales ${ }^{32}$. La provisionalidad viene dada por los términos literales del art. $86 \mathrm{CE}$, esto es, por los ideados constitucionalmente para definir la relación entre el gobierno y las Cortes Generales en este supuesto de aprobación por aquél sin delegación de una norma con rango de ley, conscientes de que éstas «ejercen la potestad legislativa del Estado» (art. 66.2 CE).

En consecuencia, aprobado un decreto-ley, tras su publicación en el $B O E$, «empieza a surtir efectos en el ordenamiento jurídico en el que provisionalmente se inserta como una norma dotada con fuerza y valor de ley, debiendo ser sometido inmediatamente a debate y votación por el Congreso de los Diputados en el ineludible plazo que dispone el art. 86, núm. 2, de la CE. La doble vía que a estos efectos fiscalizadores prevé el art. 86 de la Constitución, en sus apartados segundo y tercero, ha venido a decantarse en la práctica parlamentaria en el sentido del necesario y previo pronunciamiento sobre la totalidad del decreto-ley. Pero, una vez convalidado éste, se posibilita el acudir a tramitarlo como proyecto de ley por el procedimiento de urgencia (art. 86, núm. 3, CE), si bien es cierto que nada se opone a una interpretación alternativa de ambas vías, quedando este punto al criterio de oportunidad que pueda establecer en un futuro el

ámbito laboral, que afirma en su art. 1.1: «El presente real decreto-ley tiene por objeto regular la planificación y financiación del sistema de formación profesional para el empleo en el ámbito laboral, la programación y ejecución de las acciones formativas, el control, el seguimiento y el régimen sancionador, así como el sistema de información, la evaluación, la calidad y la gobernanza del sistema, conforme a los fines y principios señalados en los arts. 2 y 3 ».

${ }^{31}$ En la línea, por poner tres ejemplos solamente, del Real Decreto-ley 5/1983, de 1 de septiembre, sobre medidas urgentes para reparar los daños causados por las recientes inundaciones en el País Vasco, Cantabria, Asturias, Burgos y Navarra; del Real Decreto-ley 6/2011, de 13 de mayo, por el que se adoptan medidas urgentes para reparar los daños causados por los movimientos sísmicos acaecidos el 11 de mayo de 2011 en Lorca (Murcia), o del Real Decreto-ley 2/2015, de 6 de marzo, por el que se adoptan medidas urgentes para reparar los daños causados por las inundaciones y otros efectos de los temporales de lluvia, nieve y viento acaecidos en los meses de enero, febrero y marzo de 2015, que hasta aprueban la existencia de fuerza mayor a los efectos de los arts. 47 (suspensión) y 51 (extinción) del texto refundido de la Ley del Estatuto de los Trabajadores (art. 12.1 del Real Decreto-ley 2/2015).

32 Incluso decretos-leyes que no se transforman en leyes ordinarias son modificados después por ley en algunas de sus disposiciones, sobre todo por parte de las leyes de presupuestos generales del Estado. Vid., verbigracia y por todas, la disposición final vigésimo quinta de la Ley 2/2012, de 29 de junio, de Presupuestos Generales del Estado para el año 2012, que modifica el art. 6 del Real Decreto-ley 13/2009, de 26 de octubre, por el que se crea el Fondo Estatal para el Empleo y la Sostenibilidad Local. 
Congreso de los Diputados» ${ }^{33}$. La provisionalidad desaparece, por tanto, cuando se convalida (o se deroga, evidentemente) el decreto-ley por el Congreso de los Diputados, convocado al efecto si no estuviere reunido, que habrá de debatirlo y se pronunciará expresamente, mediante una votación de totalidad producida en el plazo de los treinta días siguientes a su promulgación, sobre su convalidación o derogación, para lo cual el reglamento establecerá un procedimiento especial y sumario (art. 86.2 CE) ${ }^{34}$. Ha sido frecuente, especialmente con las reformas laborales y de seguridad social, la tramitación de los decretos-leyes como proyectos de ley de conformidad con lo prevenido en el art. $86.3 \mathrm{CE}^{35}$. En ocasiones su rápida transformación en ley, o excepcionalmente su derogación por una ley de contenido diverso al cambiar el criterio del gobierno ${ }^{36}$,

33 STC 29/1982, de 31 de mayo, FJ 2.

34 Si bien suele procederse a la convalidación parlamentaria, no siempre es así. Vid., por ejemplo, la reciente Resolución de 6 de abril de 2016 de la Presidencia del Parlamento de Andalucía (Boletín Oficial de la Junta de Andalucía de 11 de mayo de 2016): «El Pleno del Parlamento de Andalucía el 6 de abril de 2016, en el transcurso de la sesión celebrada los días 6 y 7 del mismo mes y año, de conformidad con lo dispuesto en el art. 110 del Estatuto de Autonomía para Andalucía y en el punto tercero de la Resolución de la Presidencia de 5 de junio de 2008, sobre control por el Parlamento de los decretos leyes dictados por el Consejo de Gobierno, ha acordado no convalidar el Decreto-ley 1/2016, de 15 de marzo, por el que se modifican la Ley $2 / 2015$, de 29 de diciembre, sobre medidas urgentes para favorecer la inserción laboral, la estabilidad en el empleo, el retorno del talento y el fomento del trabajo autónomo; el Decreto-ley 6/2014, de 29 de abril, por el que se aprueba el programa “Emple@Joven” y la iniciativa “@mprende+”, y el Decreto-ley 9/2014, de 15 de julio, por el que se aprueba el programa "Emple@30+", quedando, en consecuencia, derogado».

35 Por ejemplo, hallan su origen en un decreto-ley (figuran entre paréntesis en el listado siguiente, RD-1) estas leyes de contenido laboral o de seguridad social: Ley 10/1994, de 19 de mayo, sobre medidas urgentes de fomento de la ocupación (RD-1 18/1993); Ley 63/1997, de 26 de diciembre, sobre medidas urgentes para la mejora del mercado de trabajo y el fomento de la contratación indefinida (RD-1 8/1997); Ley 64/1997, de 26 de diciembre, por la que se regulan incentivos en materia de Seguridad Social y de carácter fiscal para el fomento de la contratación indefinida y la estabilidad en el empleo (RD-1 9/1997); Ley 12/2001, de 9 de julio, sobre medidas urgentes de reforma del mercado de trabajo para el incremento del empleo y la mejora de su calidad (RD-1 5/2001); Ley 35/2002, de 12 de julio, sobre medidas para el establecimiento de un sistema de jubilación gradual y flexible (RD-1 16/2001); Ley 35/2010, de 17 de septiembre, sobre medidas urgentes para la reforma del mercado de trabajo (RD-1 10/2010); Ley 3/2012, de 6 de julio, sobre medidas urgentes para la reforma del mercado laboral (RD-1 3/2012); Ley 11/2013, de 26 de julio, sobre medidas de apoyo al emprendedor y de estímulo del crecimiento y de la creación de empleo (RD-1 4/2013); Ley $1 / 2014$, de 28 de febrero, para la protección de los trabajadores a tiempo parcial y otras medidas urgentes en el orden económico y social (RD-1 11/2013); Ley 18/2014, de 15 de octubre, sobre aprobación de medidas urgentes para el crecimiento, la competitividad y la eficiencia (RD-1 8/2014), o Ley 30/2015, de 9 de septiembre, por la que se regula el Sistema de Formación Profesional para el empleo en el ámbito laboral (RD-1 4/2015).

${ }^{36}$ La Ley 45/2002, de 12 de diciembre, sobre medidas urgentes para la reforma del 
hace que concluyan los cuestionamientos acerca de la existencia o no de extraordinaria y urgente necesidad, y verse la discusión sobre los contenidos objeto de la regulación.

Procede ahora centrar el estudio en la valoración del presupuesto fáctico habilitante (en caso de extraordinaria y urgente necesidad). Y es que el juicio de constitucionalidad sobre un decreto-ley pasa, en primer lugar, por la determinación de la existencia o no de extraordinaria y urgente necesidad, asunto que merece una decisión específica. Esta pauta metodológica quedó fijada pronto, en la STC 29/1982, de 31 de mayo ${ }^{37}$. Así lo ha hecho el TC en las sesenta y siete sentencias que se citan a pie de página, pronunciadas en resolución de recursos y cuestiones de inconstitucionalidad, así como de conflictos de competencias, sobre decretos-leyes aprobados por el gobierno de España ${ }^{38}$, amén de en otras

sistema de protección por desempleo y mejora de la ocupabilidad, derogó expresamente, con una huelga general entretanto (20 de junio de 2002), apartándose parcialmente de su contenido, el Real Decreto-ley 5/2002, de 24 de mayo, el cual, sin embargo, fue declarado inconstitucional y nulo, precisamente a causa de la vulneración del art. 86.1 CE, por la STC 68/2007, de 28 de marzo.

37 «De esta forma, la ineludible exigencia constitucional de la existencia de un presupuesto habilitante para dictar un decreto-ley se vincula a éste como justificación de su constitucionalidad y puede ser contrastada tanto en vía parlamentaria como ante este TC, permitiendo, en este último supuesto, un pronunciamiento previo y diferenciado del que igualmente pueda formularse sobre el contenido específico de la norma» (STC 29/1982, FJ 3. ${ }^{\circ}$ ).

38 Estas sentencias, pronunciadas por el Pleno del TC (figura entre paréntesis el decreto-ley enjuiciado, RD-1) son las SSTC 29/1982, de 31 de mayo (RD-1 10/1981, sobre inspección y recaudación de la Seguridad Social); 6/1983, de 4 de febrero (RD-1 11/1979, sobre medidas urgentes de financiación de las haciendas locales); 41/1983, de 18 de mayo (mismo que la anterior); 51/1983, de 14 de junio (mismo que las anteriores); 111/1983, de 2 de diciembre (RD-1 2/1983, de 23 de febrero, sobre expropiación, por razones de utilidad pública e interés social, de los bancos y sociedades que componen el grupo Rumasa, S. A.); 29/1986, de 20 de febrero (RD-1 8/1983, de 30 de noviembre, sobre reconversión y reindustrialización); 60/1986, de 20 de mayo (RD-1 22/1982, de 7 de diciembre, sobre medidas urgentes de reforma administrativa); 3/1988, de 21 de enero (RD-1 3/1979, de 26 de enero, sobre protección de la seguridad ciudadana); 93/1988, de 24 de mayo (mismo que la anterior); 177/1990, de 15 de noviembre (RD-1 8/1983, ya citado); 23/1993, de 21 de enero (RD-1 1/1986, de 14 de marzo, sobre medidas urgentes administrativas, financieras, fiscales y laborales); 182/1997, de 28 de octubre (RD-1 5/1992, de 21 de julio, sobre medidas presupuestarias urgentes); 11/2002, de 17 de enero (RD-1 8/1994, de 5 de agosto, por el que se suprimieron como corporaciones de Derecho público las Cámaras Oficiales de la Propiedad Urbana); 137/2003, de 3 de julio (RD-1 12/1995, de 28 de diciembre, sobre medidas urgentes en materia presupuestaria, tributaria y financiera); 108/2004, de 30 de junio (RD-1 12/1996, de 26 de julio, sobre medidas tributarias urgentes); 245/2004, de 16 de diciembre (RD-1 2/1996, de 26 de enero, sobre determinadas prestaciones patrimoniales de carácter público); 155/2005, de 9 de junio (RD-1 14/1998, de 9 de octubre, sobre adhesión de España a diversos acuerdos del Fondo Monetario Internacional); 189/2005, de 7 de julio (RD-1 7/1996, de 7 de junio, sobre medidas urgentes de carácter fiscal y de fomento y liberalización de la actividad económica); 
329/2005, de 15 de diciembre (RD-1 1/1997, de 31 de enero, por el que se incorpora al Derecho español la Directiva 95/47/CE de la Comisión Europea, de 24 de octubre, sobre el uso de normas para la transmisión de señales de televisión y se aprueban medidas adicionales para la liberalización del sector, y RD-1 16/1997, de 13 de septiembre, sobre el uso de normas para la transmisión de señales de televisión y medidas adicionales para la liberalización del sector); 332/2005, de 15 de diciembre (RD-1 7/2000, de 23 de junio, sobre medidas urgentes en el sector de las telecomunicaciones); 68/2007, de 28 de marzo (RD-1 5/2002, de 24 de mayo, sobre medidas urgentes para la reforma del sistema de protección por desempleo y mejora de la ocupabilidad); 31/2011, de 17 de marzo (RD-1 6/2000, de 23 de junio, sobre medidas urgentes de intensificación de la competencia en mercados de bienes y servicios); 137/2011, de 14 de septiembre (RD-1 4/2000, de 23 de junio, sobre medidas urgentes de liberalización en el sector inmobiliario y transportes); 1/2012, de 13 de enero (RD-1 9/2000, de 6 de octubre, de modificación del Real Decreto Legislativo 1302/1986, de 28 de junio, sobre evaluación de impacto ambiental); 100/2012, de 8 de mayo (RD-1 7/1993, de 21 de mayo, sobre medidas urgentes de adaptación y modificación del Impuesto sobre el Valor Añadido, del Impuesto Especial sobre determinados Medios de Transporte, del Impuesto General Indirecto Canario, del Arbitrio sobre la Producción e Importación en las Islas Canarias y de la Tarifa Especial del Arbitrio Insular a la Entrada de Mercancías); 170/2012, de 4 de octubre (RD-1 6/2000, ya citado); 233/2012, de 13 de diciembre (mismo que la anterior); 237/2012, de 13 de diciembre (RD-1 2/2004, de 18 de junio, por el que se modifica la Ley 10/2001, de 5 de julio, del Plan Hidrológico Nacional); 39/2013, de 14 de febrero (RD-1 4/2006, de 24 de febrero, por el que se modifican las funciones de la Comisión Nacional de Energía); 51/2013, de 28 de febrero (RD-12/2004, ya citado); 64/2013, de 14 de marzo (mismo que la anterior); 182/2013, de 23 de octubre (RD-1 9/2009, de 26 de junio, sobre reestructuración bancaria y reforzamiento de los recursos propios de las entidades de crédito); 83/2014, de 29 de mayo (RD-1 5/2000, de 23 de junio, sobre medidas urgentes de contención del gasto farmacéutico público y de racionalización del uso de los medicamentos); 96/2014, de 12 de junio (RD-1 14/2010, de 23 de diciembre, por el que se establecen medidas urgentes para la corrección del déficit tarifario del sector eléctrico); 109/2014, de 26 de junio (mismo que la anterior); 142/2014, de 11 de septiembre (RD-1 1/2009, de 23 de febrero, sobre medidas urgentes en materia de telecomunicaciones); 183/2014, de 6 de noviembre (RD-1 29/2012, de 28 de diciembre, sobre mejora de gestión y protección social en el sistema especial para empleados de hogar y otras medidas de carácter económico y social); 27/2015, de 19 de febrero (RD-1 11/2013, de 2 de agosto, para la protección de los trabajadores a tiempo parcial y otras medidas urgentes en el orden económico y social); 47/2015, de 5 de marzo (RD-1 2/2011, de 18 de febrero, para el reforzamiento del sistema financiero); 48/2015, de 5 de marzo (RD-1 1/2012, de 27 de enero, por el que se procede a la suspensión de los procedimientos de preasignación de retribución y a la supresión de los incentivos económicos para nuevas instalaciones de producción de energía eléctrica a partir de cogeneración, fuentes de energía renovables y residuos); 81/2015, de 30 de abril (RD-1 20/2012, de 13 de julio, sobre medidas para garantizar la estabilidad presupuestaria y de fomento de la competitividad); 105/2015, de 28 de mayo (RD-1 1/2012, ya citado); 106/2015, de 28 de mayo (mismo que la anterior); 156/2015, de 9 de julio (RD-1 20/2012, ya citado); 196/2015, de 24 de septiembre (RD-1 12/2011, de 26 de agosto, por el que se modifica la Ley 1/2000, de 7 de enero, de Enjuiciamiento Civil, para la aplicación del convenio internacional sobre el embargo preventivo de buques y se regulan competencias autonómicas en materia de policía de dominio público hidráulico); 197/2015, de 24 de septiembre (RD-1 4/2013, de 22 de febrero, sobre medidas de apoyo al emprendedor y de estímulo del crecimiento y de la creación de empleo); 199/2015, de 24 de septiembre (RD-1 8/2014, de 4 de julio, sobre aprobación de medidas urgentes para el crecimiento, la competitividad y la eficiencia); 211/2015, de 8 de octubre 
referentes al ámbito competencial de los consejos de gobierno de las Comunidades Autónomas. Las dos exigencias, el carácter extraordinario y la urgencia, tienen que darse simultáneamente. La habilitación exige que se esté en un caso extraordinario, ajeno a la previsión y la planificación propias del buen desempeño del gobierno (art. $97 \mathrm{CE}$ ), esto es, en una situación generada por imponderables de muy diversa índole, desde inundaciones y terremotos hasta la aparición repentina de graves crisis laborales, sociales, económicas, financieras o presupuestarias con insuficiencias o deficiencias legales ${ }^{39}$. Asimismo, la «justificación del decreto-ley podrá también darse en aquellos casos en que por circunstancias o factores, o por su compleja

(mismo que la anterior); 215/2015, de 22 de octubre (RD-1 20/2011, de 30 de diciembre, sobre medidas urgentes en materia presupuestaria, tributaria y financiera para la corrección del déficit público); 243/2015, de 30 de noviembre (RD-1 20/2012, ya citado); 5/2016, de 21 de enero (RD-1 8/2011, de 1 de julio, sobre medidas de apoyo a los deudores hipotecarios, de control del gasto público y cancelación de deudas con empresas y autónomos contraídas por las entidades locales, de fomento de la actividad empresarial e impulso de la rehabilitación y de simplificación administrativa); 18/2016, de 4 de febrero (RD-1 20/2012, ya citado); 26/2016, de 18 de febrero (RD-1 14/2012, de 20 de abril, sobre medidas urgentes de racionalización del gasto público en el ámbito educativo); 37/2016, de 3 de marzo (RD-1 20/2012, ya citado); 38/2016, de 3 de marzo (RD-1 5/2013, de 6 de septiembre, por el que se adoptan determinadas medidas urgentes en relación con la implantación, para el curso 2013-2014, del sistema de tratamiento integrado de las lenguas en los centros docentes no universitarios de las Illes Balears); 54/2016, de 17 de marzo (RD-1 14/2012, ya citado); 66/2016, de 14 de abril (mismo que la anterior); 67/2016, de 14 de abril (mismo que las anteriores); 68/2016, de 14 de abril (mismo que las anteriores); 70/2016, de 14 de abril (RD-1 7/2013, de 28 de junio, sobre medidas urgentes de naturaleza tributaria, presupuestaria y de fomento de la investigación, el desarrollo y la innovación); 84/2016, de 28 de abril (RD-1 14/2012, ya citado); 119/2016, de 23 de junio (RD-1 20/2012, ya citado); 125/2016, de 7 de julio (RD-1 13/2005, de 28 de octubre, por el que se modifica la Ley 4/1986, de 8 de enero, de Cesión de Bienes del Patrimonio Sindical Acumulado); 126/2016, de 7 de julio (RD-1 10/2014, de 1 de agosto, por el que se conceden créditos extraordinarios y suplementos de crédito en el presupuesto de los Ministerios de Asuntos Exteriores y Cooperación, de Defensa y de Agricultura, Alimentación y Medio Ambiente); 139/2016, de 21 de julio (RD-1 16/2012, de 20 de abril, sobre medidas urgentes para garantizar la sostenibilidad del Sistema Nacional de Salud y mejorar la calidad y seguridad de sus prestaciones); 169/2016, de 6 de octubre (RD-1 7/2015, de 14 de mayo, por el que se conceden créditos extraordinarios y un suplemento de crédito por importe de 856.440.673,35 euros en el presupuesto del Ministerio de Defensa para atender al pago de obligaciones correspondientes a programas especiales de armamento y a la realización de otras actuaciones del Departamento); 183/2016, de 3 de noviembre (RD-1 16/2012, ya citado), y 195/2016, de 16 de noviembre (RD-1 /2014, de 4 de julio, sobre aprobación de medidas urgentes para el crecimiento, la competitividad y la eficiencia).

${ }^{39}$ La necesidad de reformar la legislación laboral para combatir el desempleo originado por las crisis económicas y financieras, habitualmente de ámbito internacional, se ha convertido en una justificación argüida como irrefutable por los gobiernos, con o sin acuerdos procedentes de la concertación social, desde aquel limitado Real Decreto-ley 18/1993, de 3 de diciembre, sobre medidas urgentes de fomento de la ocupación, hasta el amplio Real Decreto-ley $3 / 2012$, de 10 de febrero, sobre medidas urgentes para la reforma del mercado labo- 
concurrencia, no pueda acudirse a la medida legislativa ordinaria sin hacer quebrar la efectividad de la acción requerida, bien por el tiempo a invertir en el procedimiento legislativo o por la necesidad de la inmediatividad de la medida ${ }^{40}$. Mas la naturaleza extraordinaria del caso no basta, pues se requiere que el gobierno, para cumplir cabalmente sus funciones constitucionales, deba adoptar ineludiblemente medidas urgentes con requerimientos normativos consistentes en la aprobación inmediata de una disposición con fuerza de ley, imposibles de atender acudiendo a la iniciativa legislativa ordinaria, aunque sea a través del trámite de urgencia ${ }^{41}$.

El gobierno ha de justificar la concurrencia del presupuesto habilitante en la exposición de motivos del decreto-ley correspondiente ${ }^{42}$. Se trata de una justificación basada en la valoración que realiza desde los hechos de los que dispone y los criterios políticos que en su virtud fija, entre los que habitualmente se encontrarán, si se han alcanzado, los acuerdos en la materia, base quizá del contenido, con las organizaciones sindicales y empresariales más representativas ${ }^{43}$. El TC suele admitir con flexibilidad la

ral. Vid. al respecto M. C. PALOmeque LÓPEZ, «La abusiva utilización del decreto-ley por la política de empleo», Revista de Derecho Social, núm. 19 (2002), pp. 77-90.

40 STC 111/1983, de 2 de diciembre, FJ 6. ${ }^{\circ}$

${ }^{41}$ El TC estima acorde a las exigencias del art. 86.1 CE la «necesidad relativa respecto de situaciones concretas de los objetivos gubernamentales que, por razones difíciles de prever, requieren una acción normativa inmediata en un plazo más breve que el requerido por la vía normal o por el procedimiento de urgencia para la tramitación parlamentaria de las leyes» (STC 6/1983, de 4 de febrero, FJ 5.').

42 «Es también constante en nuestra jurisprudencia la afirmación de que incumbe al gobierno autor del decreto-ley expresar (explicitar de una forma razonada, según la STC 189/2005, de 7 de julio) los motivos de urgencia, que son los que ha de analizar este Tribunal cuando se niegue su eficacia habilitante para dictar aquel, y que habrán tenido reflejo en la exposición de motivos de la norma, en el debate parlamentario sobre su convalidación o en el expediente de elaboración de aquélla» (STC 125/2016, de 7 de julio, FJ 3. ${ }^{\circ}$ ).

${ }^{43}$ Con todo, advierte la STC 68/2007, de 28 de marzo: «Es indudable, y no parece necesario recordarlo aquí, el valor trascendente del diálogo social en nuestro Estado social y democrático de Derecho (art. 1.1 CE) y la importancia de la participación de las organizaciones sindicales y empresariales en el procedimiento de elaboración de aquellas leyes que puedan afectar a los intereses económicos y sociales a cuya defensa y promoción contribuyen significadamente (art. $7 \mathrm{CE}$ ). Es claro también que estos procesos de diálogo social, precisamente por venir en numerosas ocasiones referidos a proyectos de reforma de las instituciones del mercado de trabajo o de los sistemas de protección social, pueden estar condicionados por la necesidad de dar respuesta inmediata a coyunturas económicas o sociales problemáticas, en las que la utilización de la legislación de urgencia, tras la conclusión del proceso de diálogo, puede aparecer plenamente justificada (STC 23/1993, de 21 de enero, FJ.$^{\circ}{ }^{\circ}$ ). Sin embargo, y en ausencia de estas razones, no puede aceptarse que la necesaria participación de los agentes sociales en el procedimiento legislativo - en lo que en ocasiones se ha denominado "legislación prenegociada" - implique enervar el ejercicio regular por las Cortes Generales de la potestad legislativa del Estado (art. 66.2 CE)» (FJ 11). 
valoración política, más o menos fundada en datos o hechos sobrevenidos en un contexto inesperado y desmedido ${ }^{44}$, salvo que estime que no ha habido justificación ${ }^{45}$ o que se ha producido un «uso abusivo o arbitrario» por el gobierno, razón que le llevaría a «rechazar la definición que los órganos políticos hagan de una situación determinada como caso de extraordinaria y urgente necesidad, de tal naturaleza que no pueda ser atendida por la vía del procedimiento legislativo de urgencia», porque «es claro que el ejercicio de esta potestad de control del Tribunal implica que dicha definición sea explícita y razonada, y que exista una conexión de sentido entre la situación definida y las medidas que en el decreto-ley se adoptan». $\mathrm{Y}$ es que: «El peso que en la apreciación de lo que haya de considerarse como caso de extraordinaria y urgente necesidad es forzoso conceder al juicio puramente político de los órganos a los que incumbe la dirección política del Estado no puede ser obstáculo para extender

44 Afirma la STC 68/2007, de 28 de marzo, en su FJ 6. ${ }^{\circ}$, que: «Es claro que el ejercicio de la potestad de control que compete a este Tribunal implica que la definición por los órganos políticos de una situación de "extraordinaria y urgente necesidad" sea explícita y razonada, y que exista una conexión de sentido o relación de adecuación entre la situación definida que constituye el presupuesto habilitante y las medidas que en el decreto-ley se adoptan (STC 29/1982, de 31 de mayo, FJ $3 .^{\circ}$ ), de manera que estas últimas guarden una relación directa o de congruencia con la situación que se trata de afrontar» (STC 182/1997, de 28 de octubre, FJ $3 .^{\circ}$ ). Ello no quiere decir que tal definición expresa «de la extraordinaria y urgente necesidad» haya de contenerse siempre en el propio real decreto-ley, sino que tal presupuesto cabe deducirlo igualmente de una pluralidad de elementos. A este respecto conviene recordar que el examen de la concurrencia del citado presupuesto habilitante de la «extraordinaria y urgente necesidad» siempre se ha de llevar a cabo mediante la valoración conjunta de todos aquellos factores que determinaron al gobierno a dictar la disposición legal excepcional y que son, básicamente, «los que quedan reflejados en la exposición de motivos de la norma, a lo largo del debate parlamentario de convalidación y en el propio expediente de elaboración de la misma» (SSTC 29/1982, de 31 de mayo, FJ 4. ${ }^{\circ} ; 182 / 1997$, de 28 de octubre, FJ 4..$^{\circ}$; 11/2002, de 17 de enero, FJ 4. ${ }^{\circ}$, y 137/2003, de 3 de julio, FJ 3. ${ }^{\circ}$ ), debiendo siempre tenerse presentes «las situaciones concretas y los objetivos gubernamentales que han dado lugar a la aprobación de cada uno de los decretos-leyes enjuiciados (SSTC 6/1983, de 4 de febrero, FJ 5. ${ }^{\circ}$; 182/1997, de 28 de octubre, FJ 3. ${ }^{\circ} ; 11 / 2002$, de 17 de enero, FJ $4 .^{\circ}$, y $137 / 2003$, de 3 de julio, FJ $\left.3 .^{\circ}\right)_{\gg .}$.

${ }^{45}$ Argumenta, asimismo, la STC 68/2007, de 28 de marzo, en su FJ 12, que: «Hemos de concluir, por todo lo señalado, que en el caso de la norma que ahora se analiza el gobierno no ha aportado ninguna justificación que permita apreciar la existencia de la situación habilitante requerida por el art. 86.1 CE. Los argumentos que al respecto se utilizan en el preámbulo del Real Decreto-ley no sólo resultan marcadamente teóricos y abstractos, impidiendo con ello todo control de contraste con la realidad, sino que, en buena medida, han sido matizados — cuando no neutralizados - por la propia percepción de la realidad transmitida por el gobierno en el debate parlamentario de convalidación. Y, en todo caso, en ningún momento se ha justificado cuáles serían los perjuicios u obstáculos que, para la consecución de los objetivos perseguidos, se seguirían de su tramitación por el procedimiento legislativo parlamentario, en su caso por el trámite de urgencia». 
también el examen sobre la competencia habilitante al conocimiento del TC, en cuanto sea necesario para garantizar un uso del decreto-ley adecuado a la Constitución» ${ }^{46}$.

También efectúa el Congreso de los Diputados, en el mencionado procedimiento de convalidación, una valoración, con un «razonable margen de discrecionalidad», de la existencia de las circunstancias habilitantes del art. 86.1 CE, así como del cumplimiento de los límites señalados para la materia objeto de regulación y, por supuesto, de la idoneidad, en opinión de los grupos parlamentarios, del contenido. La aprobación, en votación de totalidad siempre, de la convalidación del decreto-ley no salva su constitucionalidad, pues su competencia «no les autoriza [...] para incluir en el decreto-ley cualquier género de disposiciones: ni aquellas que, por su contenido y de manera evidente, no guarden relación alguna, directa ni indirecta, con la situación que se trata de afrontar ni, muy especialmente, aquellas que, por su estructura misma, independientemente de su contenido, no modifican de manera instantánea la situación jurídica existente, pues de ellas difícilmente podrá predicarse la justificación de la extraordinaria y urgente necesidad» ${ }^{47}$. La convalidación no empece obviamente el enjuiciamiento por el TC de los decretos-leyes, que, a diferencia de lo que sucede con el Congreso de los Diputados, podrá determinar tanto la constitucionalidad de la norma en su conjunto ${ }^{48}$ como de cada una de sus disposiciones por separado ${ }^{49}$.

${ }^{46}$ Los entrecomillados de este párrafo corresponden al FJ 3. ${ }^{\circ}$ de la STC 29/1982, de 31 de mayo, la cual, como se ha señalado, señaló las pautas interpretativas en esta materia que se han venido siguiendo ininterrumpidamente.

${ }^{47}$ Ibid., nota 39.

${ }^{48}$ Como, por ejemplo, los citados Real Decreto-ley 5/2002, de 24 de mayo, sobre medidas urgentes para la reforma del sistema de protección por desempleo y mejora de la ocupabilidad (por la STC 68/2007, de 28 de marzo), y Real Decreto-ley 13/2005, de 28 de octubre, por el que se modifica la Ley 4/1986, de 8 de enero, de Cesión de Bienes del Patrimonio Sindical Acumulado (por la STC 125/2016, de 7 de julio).

${ }^{49}$ Como, por ejemplo, los citados Real Decreto-ley 9/2000, de 6 de octubre, de modificación del Real Decreto Legislativo 1302/1986, de 28 de junio, de Evaluación de Impacto Ambiental (por la STC 1/2012, de 13 de enero), y Real Decreto-ley 14/2012, de 20 de abril, sobre medidas urgentes de racionalización del gasto público en el ámbito educativo (por la STC 26/2016, de 18 de febrero). 


\section{LA DISPOSICIÓN ADICIONAL CUARTA DE LA LEY DEL PATRIMONIO SINDICAL ACUMULADO DE 1986 Y SU MODIFICACIÓN DE 2005, DECLARADA INCONSTITUCIONAL POR LA STC 125/2016}

Indica la exposición de motivos de la Ley 4/1986, de 8 de enero, de Cesión de Bienes del Patrimonio Sindical Acumulado (LPSA) ${ }^{50}$, que: «Dos son los problemas fundamentales cuya solución aborda la presente Ley: por una parte, el grave y complejo problema de la titularidad de los bienes y derechos procedentes de la antigua organización sindical y de las demás entidades sindicales anteriores al nuevo sistema de libertad y pluralidad sindicales consagrado por la Constitución, y, por otra, el contenido histórico derivado de la incautación de los bienes de las organizaciones sindicales democráticas como consecuencia de la guerra civil española, al tener que cumplir, hoy día, con las funciones que la propia Norma Fundamental española les reconoce y garantiza» ${ }^{51}$. El gobierno se había comprometido en el Acuerdo Económico y Social (AES) de $1984^{52}$ a tramitar un proyecto de ley sobre «la adjudicación en usufructo del Patrimonio Sindical Acumulado» ${ }^{53}$, previa consulta a

50 Cuyo Reglamento fue aprobado por el Real Decreto 1671/1986, de 1 de agosto, modificado tan solo por el Real Decreto 930/1993, de 18 de junio, que cambió la composición de la Comisión Consultiva del Patrimonio Sindical prevista en el art. 6 LPSA tras la declaración de la inconstitucionalidad del inciso «más representativas» del apartado 2 de dicho artículo por la STC 183/1992, de 16 de noviembre.

51 Vid. M. C. Palomeque López, Derecho Sindical español, 1. a ed., Madrid, Tecnos, 1986, pp. 111-112 (2. ${ }^{a}$ ed., 1988; 3. ${ }^{a}$ ed., 1989, reimp., 1990; 4. ${ }^{a}$ ed., 1991, y 5. . ed., 1994), que a los pocos meses de la entrada en vigor de la LPSA, junto al estudio jurídico, facilita datos del inventario de bienes y derechos del «patrimonio sindical histórico» partiendo del informe elaborado por la consultora Richard Ellis (CBRE), multinacional británica especializada en el sector inmobiliario, por encargo del entonces Ministerio de Trabajo y Seguridad Social. Consúltese, asimismo, M. C. PAlomeque López y M. Álvarez DE la Rosa, Derecho del Trabajo, 24. a ed., Madrid, Centro de Estudios Ramón Areces, 2016, pp. 326-328 («el patrimonio de la OSE estaba compuesto por 1.168 inmuebles valorados en 1978 en 44.000 millones de pesetas»).

52 Suscrito el 9 de octubre de 1984 por el gobierno, la Unión General de Trabajadores (UGT), la Confederación Española de Organizaciones Empresariales (CEOE) y la Confederación Española de la Pequeña y Mediana Empresa (CEPYME), publicado en el Boletín Oficial del Estado, sección de «Disposiciones generales», el 10 de octubre de 1984. Vid. E. Rojo Torrecilla y F. Pérez Amorós, «El Acuerdo Económico y Social», Revista de Política Social, núm. 145 (1985), pp. 55-78.

53 «Constituyen el Patrimonio Sindical Acumulado todos los bienes, derechos y obligaciones de contenido patrimonial que, habiendo pertenecido a la antigua Organización Sindical, se transfirieron íntegramente al Organismo Autónomo Administración Institucional 
las organizaciones sindicales y empresariales más representativas ${ }^{54}$. La previsión del art. 22 AES se satisfizo esencialmente con lo regulado en el art. 3 LPSA: «Los bienes y derechos a que se refiere el artículo primero de la presente Ley serán objeto de cesión en uso en favor de los sindicatos de trabajadores y de las asociaciones empresariales, con preferencia de quienes ostenten la condición de más representativos con arreglo a lo dispuesto en la Ley Orgánica 11/1985, de Libertad Sindical, y el resto del ordenamiento jurídico. Los bienes, derechos y obligaciones del Patrimonio Sindical Acumulado que no sean cedidos a los sindicatos y asociaciones empresariales, ni retenidos para la finalidad a que se refiere el art. 4.1 de la presente Ley, quedarán integrados en el Patrimonio del Estado y sujetos en todo a las disposiciones de su Ley reguladora, previa la realización del inventario a que hace referencia la disposición adicional primera de la presente Ley» ${ }^{55}$.

La LPSA quiso, sin embargo, ir más allá y abordar además la complicada regulación del «patrimonio sindical histórico», es decir, de «aquellos bienes y derechos que en su día fueron incautados a los sindicatos, de manera que se restituya a éstos en el presente lo que otrora se les incautó. Para ello se exigirá, no obstante, un doble condicionamiento, subjetivo y objetivo. Subjetivamente, la restitución se hará a los sindicatos que acrediten ser los legítimos sucesores de los que en su momento existieron, dando a la expresión "sucesor" el sentido que le confieren los reiterados informes del propio Comité de Libertad Sindical de la OIT. Objetivamente, la restitución alcanzaría a los propios bienes que en su momento se incautaron, de ahí que si esta restitución no fuera ya posible, bien por haber pasado los bienes a poder de terceros, bien por haber aquéllos desaparecido o sufrido alteraciones sustanciales que impidan su concordancia íntegra con los

de Servicios Socio-Profesionales por virtud del Real Decreto-ley 19/1976, de 8 de octubre, así como todos aquellos que constituían los patrimonios privativos de los antiguos sindicatos y demás entidades sindicales que, conforme a la Ley Sindical 2/1971, de 17 de febrero, tenían personalidad jurídica propia» (art. 1.1 LPSA). Determina la disposición adicional primera de la LPSA que: «En el plazo de dieciocho meses, la Administración confeccionará un inventario actualizado de todos los bienes, derechos y obligaciones que componen el Patrimonio Sindical Acumulado, oída en todo caso la Comisión Consultiva del artículo sexto».

${ }^{54} \mathrm{El}$ art. 22 del AES (1984), cuyo epígrafe es «Patrimonio Sindical Acumulado», establecía que: «El gobierno se compromete a elevar al Parlamento en el plazo de seis meses un proyecto de ley para la adjudicación en usufructo del Patrimonio Sindical Acumulado, previa consulta con las organizaciones sindicales y empresariales más representativas» (AES, 1984).

${ }_{55}$ Vid. los arts. 6.3 ff) y 7.1 de la Ley Orgánica 11/1985, de 2 de agosto, de Libertad Sindical, así como la disposición adicional sexta del texto refundido de la Ley del Estatuto de los Trabajadores, aprobado por el Real Decreto Legislativo 2/2015, de 23 de octubre. 
bienes originarios, el Estado compensaría su valor a los sindicatos en cuestión» (exposición de motivos). Con tal fin, su disposición adicional (DA) cuarta estableció lo siguiente:

«Uno. Sin perjuicio de lo dispuesto en la presente Ley, quedarán excluidos de la misma los bienes y derechos que, por virtud de la Ley de Responsabilidades Políticas de 9 de febrero de $1939^{56}$, fueron incautados a las organizaciones sindicales o sus entes afiliados o asociados de carácter sindical entonces existentes.

Tales bienes y derechos serán reintegrados en pleno dominio a dichas organizaciones debidamente inscritos a su nombre por cuenta del Estado o, en su caso, a aquellos sindicatos de trabajadores que acrediten ser sus legítimos sucesores.

Dos. Sin embargo, si los bienes o derechos en su día incautados no pudieran ser reintegrados, por cualquier causa, conforme a lo dispuesto en el apartado anterior, el Estado compensará pecuniariamente su valor, considerando como tal el normal de mercado que a la entrada en vigor de esta Ley tendrían los citados bienes y derechos de no haber sido incautados.

Dicho valor será fijado en cada caso por decisión del Consejo de Ministros, a propuesta del ministro de Trabajo y Seguridad Social y previo informe del ministro de Economía y Hacienda».

El Real Decreto-ley 13/2005, de 28 de octubre, modifica la disposición adicional cuarta ${ }^{57}$ de la LPSA para intentar concluir, después de casi veinte años, según explica el gobierno en la exposición de motivos, «la

56 Se refiere a la Ley de 9 de febrero de 1939, de Responsabilidades Políticas (BOE de 13 de febrero de 1939), la cual dispone en su art. 1. ${ }^{\circ}$ que: «Se declara la responsabilidad política de las personas, tanto jurídicas como físicas, que desde primero de octubre de mil novecientos treinta y cuatro y antes de dieciocho de julio de mil novecientos treinta y seis contribuyeron a crear o a agravar la subversión de todo orden de que se hizo víctima a España y de aquellas otras que, a partir de la segunda de dichas fechas, se hayan opuesto o se opongan al Movimiento Nacional con actos concretos o con pasividad grave».

57 Dota a la disposición adicional cuarta de este contenido:

«1. Sin perjuicio de lo dispuesto en esta Ley, quedarán excluidos de ésta los bienes y derechos que a la entrada en vigor del Decreto de 13 de septiembre de 1936 pertenecían a las organizaciones sindicales o a personas jurídicas afiliadas, asociadas o vinculadas a aquéllas, ya entonces existentes. Tales bienes y derechos serán reintegrados en pleno dominio a dichas organizaciones debidamente inscritos a su nombre por cuenta del Estado o, en su caso, a aquellos sindicatos de trabajadores que acrediten ser sus legítimos sucesores, previa solicitud de los beneficiarios antes del 31 de enero de 2006. También serán reintegrados a las mencionadas organizaciones sindicales, con los mismos requisitos y en las mismas condiciones, aquellos bienes y derechos que, habiendo pertenecido a una organización sindical o a una persona jurídica de naturaleza mercantil, cooperativa o fundacional, que hubiera estado afiliada, asociada o vinculada a aquella en el momento de la entrada en vigor del Decreto 
restitución de los bienes y derechos del denominado "patrimonio sindical histórico" y la restauración de las situaciones jurídicas afectadas por la guerra civil» ${ }^{58}$, labor que había devenido imposible «por las exigencias que la Ley 4/1986, de 8 de enero, impuso en orden a acreditar las titularidades de los bienes y derechos del patrimonio sindical histórico [...] que no tuvieron en consideración las especiales circunstancias derivadas de la existencia de una guerra civil y un largo periodo posterior de dictadura» ${ }^{59}$, así como por «la ausencia de un plazo para la presentación de solicitudes por los reclamantes, carencia de la ley que, en la práctica, ha llevado hasta el presente la formulación de tales solicitudes ante la Administración en reclamación de los legítimos intereses de los solicitantes» ${ }^{60}$. Se completan las reglas de 1986 previendo además la restitución de bienes y derechos que hubieran pertenecido a una persona jurídica de naturaleza mercantil, cooperativa o fundacional afiliada, asociada o vinculada a una organización sindical; así como de bienes y derechos que no se incorporaron al

de 13 de septiembre de 1936, no se incorporaron al patrimonio de la antigua organización sindical por consecuencia o efecto de lo previsto en una disposición legal o reglamentaria.

2. Sin embargo, si los bienes o derechos pertenecientes a las organizaciones sindicales o a las personas jurídicas mencionadas en el apartado anterior no pudieran ser reintegrados, por cualquier causa, conforme a lo dispuesto en dicho apartado, el Estado compensará pecuniariamente su valor, considerando como tal el normal de mercado que a la entrada en vigor de esta Ley tendrían los citados bienes y derechos de haber seguido perteneciendo a aquéllas, aplicando a la cantidad resultante el interés legal del dinero desde dicha entrada en vigor hasta el último día del mes anterior al que se acuerde la compensación. Los bienes muebles situados dentro de los inmuebles se valorarán en un 3 por 100 del valor de compensación de estos últimos. Dicho valor será fijado en cada caso por decisión del Consejo de Ministros, a propuesta del ministro de Trabajo y Asuntos Sociales, y previo informe del ministro de Economía y Hacienda.

3. Los bienes y derechos cuya reintegración no se solicite en el plazo establecido se inscribirán a nombre del Estado y será de aplicación la Ley 33/2003, de 3 de noviembre, del Patrimonio de las Administraciones Públicas, y sus normas de desarrollo».

${ }^{5}$ Adviértase que en la redacción dada a la disposición adicional cuarta por el Real Decreto-ley 13/2005 pasa a citarse como norma de referencia el Decreto de 13 de septiembre de 1936, de Bienes Incautados y Embargados por el Estado, en vez de la Ley de 9 de febrero de 1939, de Responsabilidades Políticas.

59 Informó el ministro de Trabajo y Asuntos Sociales, en la sesión del Congreso de los Diputados convocada para el debate y la votación de la convalidación del Real Decretoley 13/2005, celebrada el 24 de noviembre de 2005 (el acuerdo de convalidación se publicó en el BOE de 1 de diciembre de 2005), de que, desde la entrada en vigor de la LPSA, se habían reintegrado o compensado con su valor 577 inmuebles a las organizaciones sindicales poseedoras de patrimonio histórico y de que había más de cuatro mil expedientes relativos a reclamaciones de inmuebles, cuentas y bienes de otra naturaleza. Así se recoge en el FJ 3. ${ }^{\circ}$ de la STC $125 / 2016$, de 7 de julio.

${ }^{60}$ Según el Real Decreto-ley 13/2005, la presentación de la solicitud por los beneficiarios debía presentarse antes del 31 de enero de 2006. 
patrimonio de la antigua organización sindical por consecuencia o efecto de lo previsto en una disposición legal o reglamentaria.

El Gobierno justifica en la exposición de motivos la concurrencia del presupuesto habilitante de extraordinaria y urgente necesidad básicamente con los dos argumentos siguientes ${ }^{61}$ :

a) «La continuidad de la actual regulación de la restitución del patrimonio sindical histórico provocaría la imposibilidad de cumplir el objetivo de la Ley 4/1986, de 8 de enero, como lo prueba el hecho, antes señalado, de que, a pesar del largo tiempo de aplicación de tal regulación transcurrido, no se ha culminado este proceso de restitución. Esta imposibilidad de hacer efectiva la restitución está produciendo un claro perjuicio a sus beneficiarios, que se va incrementando con el paso del tiempo, en la medida en que quienes se vieron injustamente desposeídos de sus bienes y derechos siguen sin ver reparada esta injusticia».

b) «Resulta por todo ello urgente poner fin a esta situación que está incidiendo negativamente en el cumplimiento de los fines de reparación de la incautación de los bienes de las organizaciones sindicales democráticas como consecuencia de la guerra civil y afectando, de un modo más general, a la seguridad jurídica, procediendo así a la sustitución de la anterior normativa por una nueva que elimine las disfunciones constatadas y que dé solución a un problema tan especial por su vinculación a un hecho de excepcional alteración de los principios del orden democrático. En esta apreciación de la urgencia tampoco hay que dejar de considerar la necesidad de aminorar el impacto sobre el gasto público de las actuaciones de compensación».

El 2 de febrero de 2006 ochenta y un diputados del Grupo Popular interpusieron un recurso de inconstitucionalidad, que recibiría el número 1044-2006, contra el Real Decreto-ley 13/2005 pidiendo la declaración de inconstitucionalidad y nulidad de éste en su totalidad. Denuncian que «se ha dictado con el único fin de favorecer a una organización sindical determinada en contra del principio de igualdad y del derecho de libertad sindical consagrados en los arts. 14 y $28.1 \mathrm{CE}$, en referencia a las dificultades económicas por las que atravesaba, cuando se aprobó, el sindicato Unión General de Trabajadores (UGT), que tenía que hacer frente a las responsabilidades civiles derivadas de la quiebra de una cooperativa, lo

${ }^{61}$ El ministro de Trabajo y Asuntos Sociales esgrimió, asimismo, en la sesión citada que «restituir a las organizaciones sindicales sus legítimos bienes, que fueron incautados, expoliados de forma antidemocrática», justifica «abreviar el proceso, utilizar la vía más rápida, el mecanismo más directo para realizar la total y definitiva reparación». 
que el ministro de Trabajo y Asuntos Sociales relacionó públicamente con la devolución del patrimonio incautado por el régimen franquista, según recogieron diferentes medios de comunicación». Argumentan también que «el Real Decreto-ley se dictó cuando se iniciaba un proceso de elecciones a delegados de personal y comités de empresa, momento en el que una provisión de fondos a UGT colocaba a esta organización en una evidente posición de privilegio frente a otras» (antecedente $1 .^{\circ}$ ).

Siguiendo las pautas para el enjuiciamiento de la constitucionalidad de los decretos-leyes comentadas en el apartado anterior, la STC 125/2016 procede a valorar la concurrencia en este caso de la extraordinaria y urgente necesidad que faculta al gobierno para la aprobación de estas disposiciones legislativas. Dedica a tal tarea los fundamentos jurídicos $2 .^{\circ}$ a $4 .^{\circ}$ Ya en el inicio del segundo párrafo del fundamento jurídico $3 .^{\circ}$ señala que: «El preámbulo del Real Decreto-ley impugnado expone de modo reiterativo y de no fácil comprensión los motivos a los que responde su aprobación», aseveración que viene a anticipar en gran medida el parecer del Tribunal. Considera en ese mismo fundamento jurídico, a propósito de la exposición del ministro en la sesión del Pleno del Congreso de los Diputados en la que se acordó la convalidación, que «es indudable que tan respetable finalidad puede erigirse en objetivo necesario para el gobierno, cuyo juicio sobre la importancia política del mismo no podemos sustituir. Cosa bien distinta es que colmar esa necesidad sea algo extraordinario y urgente, de modo que se justifique el recurso al decreto-ley para tratar de satisfacerla». Comienza el fundamento jurídico $4 .^{\circ}$ subrayando que: «El examen de las tres concretas medidas adoptadas en el Real Decreto-ley impugnado mediante la modificación de la disposición adicional cuarta de la Ley 4/1986, de 8 de enero, confirma nuestra convicción de que el mismo no respondía a las exigencias de una necesidad extraordinaria y urgente», y concluye en el fundamento jurídico 5. ${ }^{\circ}$ que: «El Real Decreto-ley 13/2005, de 28 de octubre, se ha dictado sin que concurriera la extraordinaria y urgente necesidad que exige el art. 86.1 CE y es, en consecuencia, inconstitucional y nulo [art. 39.1 de la Ley Orgánica del Tribunal Constitucional (LOTC)], lo que determina que debamos estimar el recurso sin necesidad de pronunciarnos sobre los otros motivos en que se fundaba».

\section{CONCLUSIÓN}

La STC 125/2016, de 7 de julio, estima el recurso de inconstitucionalidad al considerar que su aprobación no se ha ajustado a lo establecido en 
el art. 86.1 CE y, por ello, declara inconstitucional y nulo el Real Decretoley 13/2005, de 28 de octubre, por el que se modifica la Ley 4/1986, de 8 de enero, de Cesión de Bienes del Patrimonio Sindical Acumulado. Con todo: «De conformidad con el art. 40.1 LOTC, la declaración de inconstitucionalidad y de la nulidad de la citada disposición "no permitirá revisar procesos fenecidos mediante sentencia con fuerza de cosa juzgada" en los que se haya hecho aplicación de la misma. Y de acuerdo con lo que hemos dicho en casos anteriores (por ejemplo, en la STC 104/2013, de 25 de abril), más allá de ese mínimo impuesto por el art. 40.1 LOTC debemos declarar que el principio constitucional de seguridad jurídica (art. 9.3 CE) también reclama la intangibilidad de las situaciones jurídicas consolidadas decididas no sólo con fuerza de cosa juzgada, sino también en resoluciones administrativas firmes, de modo que la declaración de inconstitucionalidad sólo será eficaz en relación con nuevos supuestos o con los procedimientos administrativos y procesos judiciales en que aún no haya recaído resolución firme» (FJ 5. ${ }^{\circ}$, al que el fallo se refiere expresamente con este alcance).

Los criterios flexibles sentados por el TC para la valoración de la concurrencia del presupuesto habilitante, que han conducido a una interpretación posibilista del art. 86.1 CE, han merecido restricciones razonables en el enjuiciamiento del Real Decreto-ley 13/2005, como sucediera con anterioridad, por ejemplo, en el relativo al Real Decreto-ley 5/2002, de 24 de mayo, sobre medidas urgentes para la reforma del sistema de protección por desempleo y mejora de la ocupabilidad ${ }^{62}$. Sin perjuicio de que los procedimientos de restitución del patrimonio sindical histórico encontraran su fin, según parece, pasados dos decenios desde su regulación por la LPSA en 1986, tal objetivo debía haberse logrado con una iniciativa legislativa ordinaria. No excusa la presunción de que, seguramente, el contenido de la reforma por ley de la disposición adicional cuarta de la LPSA hubiera sido cuestionado igualmente por los mismos recurrentes, basando su petición al TC en los argumentos no estudiados en la STC 125/2016 ${ }^{63}$.

Por cierto, ¿es razonable que un recurso de inconstitucionalidad tarde en ser resuelto diez años y medio?

${ }^{62}$ Declarado inconstitucional y nulo en su totalidad, cuando ya había sido derogado, por la STC 68/2007, de 28 de marzo.

${ }^{63}$ La STC 125/2016, en su FJ 5. ${ }^{\circ}$, después de concluir que no se da el presupuesto habilitante del art. 86.1 CE, no aborda el enjuiciamiento de las demás posibles causas de inconstitucionalidad aducidas por los recurrentes: «Lo que determina que debamos estimar el recurso sin necesidad de pronunciarnos sobre los otros motivos en que se fundaba». 
